\section{Healy and Dingell lock horns}

\section{Washington}

BERNADINE Healy last week weathered her first serious storm since her appointment as director of the US National Institutes of Health (NIH), going on the offensive in a series of angry exchanges over her management of the NIH misconduct office with members of the House of Representative investigations and oversight subcommittee chaired by John Dingell (Democrat, Michigan).

But while Healy may have emerged relatively unscathed from the hearing, it seems that the troubled NIH Office of Scientific Integrity (OSI) may be in for further upheaval. Dissatisfied with Healy's moves to reform the office since her arrival at NIH, Dingell is expected to recommend that OSI be moved out of $\mathrm{NIH}$, and into the Inspector General's office at the Department of Health and Human Services.

Dingell's subcommittee wanted to explore Healy's reorganization of the OSI, which has already led to the resignation of former OSI deputy director Suzanne Hadley from the office's two most prominent misconduct investigations (see $\mathrm{Na}$ ture 352, 268; 25 July 1991). Some have suggested that Healy's manoeuvres might be linked to the fact that a Hadleyauthored draft report on alleged misconduct at Healy's former institute, the Cleveland Clinic Foundation, would reflect badly on Healy (see Nature 352, 361; 1 August 1991).

In May 1990, Healy presided over a preliminary inquiry at the clinic into allegations that a Cleveland biochemist had made false claims in NIH grant applications. Her panel concluded that the researcher had, indeed, described experiments that had not been performed, but characterized this as an honest error rather than wilful misconduct: the researcher had neglected to remove 'anticipatory writing' about experiments he had expected to perform from the final grant application.

During last week's hearing, Healy admitted freely that the preliminary Cleveland inquiry was inadequate - among other irregularities, a co-investigator on the disputed grant was included on the inquiry panel. But time and time again, Healy insisted to the congressmen that they should not focus exclusively on her actions in that initial inquiry. She had personally instigated a second inquiry, she pointed out, and when the second panel expressed grave doubts about the earlier decision, she ensured that no money under the disputed grant was ever spent.

But Dingell and his colleagues were determined to focus on the first inquiry, and tempers became steadily more frayed. "I can't handle this witness," said can, New York), at one point.

Healy also defended her handling of OSI. She said her review of OSI was influenced by serious breaches of confidentiality in the office, notably the widespread leaking of a draft OSI report on the Imanishi-Kari case and the accidental mailing of a confidential tape from the Gallo investigation to the lawyer of Gallo's former colleague Mikulas Popovic.

She said it was "preposterous" to suggest that the contining OSI investigation into the Cleveland Clinic case had biased her handling of the office and of Hadley. She stood by her decision to ask OSI director Jules Hallum to retrieve Hadley's files on the well-publicized investigations into the conduct of National Cancer Institute AIDS researcher Robert Gallo and Tufts University immunologist Thereza Imanishi-Kari. Because Hadley had left her position as a full-time investigator at OSI in March but had continued to work on the Gallo and ImanishiKari files from another office in $\mathrm{NIH}$, Healy said the result was that a "quasiindependent, satellite operation" had been set up which communicated poorly with the rest of OSI.

Despite her insistence that she has done nothing wrong in her handling of OSI, Healy has now retreated from active involvement with the office, passing responsibility to Carl Kupfer, NIH's acting director of intramural research, until OSI has released its final report on the Cleveland Clinic affair.

In a telephone interview, Healy questioned the proposal that OSI should be moved out of NIH. Dingell's concerns, she suggested, are based on the misinterpretation that OSI is the final adjudicator in cases of alleged misconduct. Despite the impression given by the leaking of the draft Imanishi-Kari report, the final judgement rests with assistant health secretary James Mason, Healy noted.

It seems unlikely that Healy has heard the last of the current OSI controversy. A statement from Bruce Singal, lawyer for Imanishi-Kari, saying that Healy "has had the courage to insist on conducting this investigation so that Dr ImanishiKari's constitutional rights are safeguarded" may serve to embroil Healy further in a controversy in which the views of the research community are becoming ever more polarized.

Healy seems resigned to a difficult path ahead. Hers is a job in which there are a lot of obstacles, she said. "If I'm to be effective, I guess I'm going to have to learn to work in that environment."

Peter Aldhous Representative Norman Lent (Republi-

\section{New head to unify schools, shed science} London

In a first step towards the planned unification of the UK university, polytechnic and college systems, the agencies that run the three sectors will now have the same chairman. Sir Ron Dearing, currently the head of the Polytechnics and Colleges Funding Council, was appointed last month to head the Universities Funding Council as well. High on his agenda when he takes his new post on 1 November, will be the unification of the two councils and transfer of science funding to the research councils, which are both part of an overall reorganization of UK higher education management.

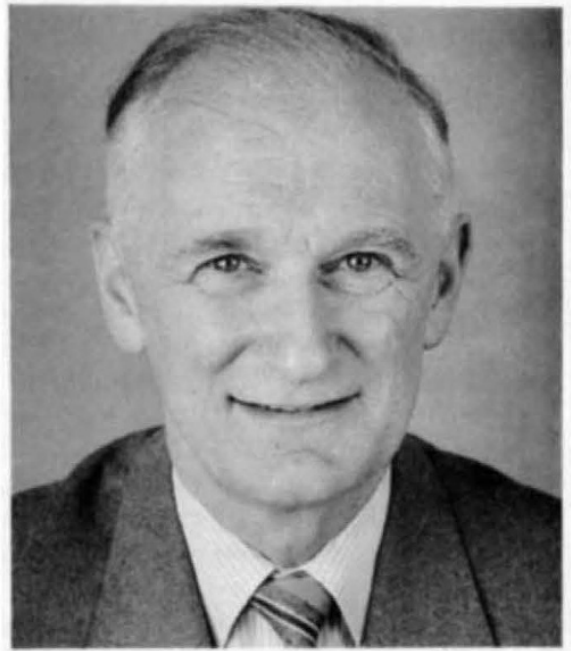

Dearing will get all of the schools and none of the research headache.

As laid out in a letter to Dearing from Education Secretary Kenneth Clarke last month, the two funding councils are to merge in April 1993. Rather than distributing council responsibilities by type of higher education institution, as is now done, unified funding councils in Scotland, Wales, Northern Ireland and England will be assigned all higher education in their geographic areas.

Unlike his predecessors, Dearing will not directly control research funding. Beginning on 1 August, 1992, the education ministry will no longer pay for the overhead portion of research grants funded by the research councils, in part to avoid the sort of accounting nightmares that have recently plagued US universities and funding agencies (see story, page 459). Rather than negotiate indirect cost rates for each institution, as US agencies do, the research councils will add a flat $\mathbf{4 0}$ per cent to all research grants to cover indirect costs, Clarke announced last week. The government will shift some $\mathbf{1 1 5 0}$ million in its 1992-93 budget from the education ministry to the research councils to cover the transferred responsibilities, he said. Christopher Anderson 